\title{
Ellagic acid production by solid-state fermentation influenced by the inert solid supports
}

\author{
Juan Buenrostro-Figueroa ${ }^{1,4}$, Alberto Ascacio-Valdés ${ }^{1}$, Leonardo Sepúlveda', Arely Prado-Barragán², \\ Miguel Ángel Aguilar-González ${ }^{3}$, Cristóbal Noé Aguilar ${ }^{1 *}$ \\ ${ }^{1}$ Food Research Department. School of Chemistry. Universidad Autónoma de Coahuila, Saltillo, 25280, Coahuila, México, ${ }^{2}$ Department of \\ Biotechnology. Universidad Autónoma Metropolitana, Unidad Iztapalapa, 09340, México D.F., ${ }^{3}$ CINVESTAV-IPN, Ramos Arizpe, 25900, \\ Coahuila, México, ${ }^{4}$ Research Center in Food and Development A.C., 33089, Cd. Delicias, Chihuahua, México
}

\section{A B S T R A C T}

\begin{abstract}
Ellagic acid and ellagitannins are defense phytochemicals and dietary polyphenols found in fruits and nuts and implicated with strong antioxidant, anticancer and antiatherosclerotic biological properties. Unfortunately, there are few reports on the bioconversion studies from ellagitannins to ellagic acid. The objective of the present work was to use of partially purified ellagitannins from pomegranate peels as inducers for production of ellagic acid by Aspergillus niger GH1 in solid-state fermentation on inert supports (perlite, polyurethane foam and nylon fiber). For total pomegranate polyphenols (TPP), two methodologies were compared. Higher recovery of TTP (70 $\mathrm{g} \mathrm{kg}{ }^{-1} \mathrm{peel}^{-1}$ in a short time $(2 \mathrm{~h})$ were obtained by filtering through a muslin cloth followed by centrifugation at $3000 \mathrm{rpm}$ for $15 \mathrm{~min}$. Production of ellagic acid and ellagitannase enzyme were evaluated. Maximum ellagic acid production (231.22 $\left.\mathrm{mg} \mathrm{g}^{-1} \mathrm{TPP}\right)$ at $24 \mathrm{~h}$ cultivation with an ellagitannase activity of $3213 \mathrm{U} \mathrm{L}^{-1}$ was obtained when using polyurethane foam as inert support. Polyurethane foam was the best solid support to produce high yields of ellagic acid production.
\end{abstract}

Keywords: Biodegradation; Ellagic acid; Ellagitannins; Polyurethane foam; Solid-state fermentation.

\section{INTRODUCTION}

An important group of phytochemical compounds known as tannins contain aromatic rings and hydroxyl groups in their molecular structure. According to Khanbabaee and van Ree (2001), tannins are grouped as follow: complex tannins, condensed tannins, gallotannins and ellagitannins.

Ellagitannins (ETs) are known like hydrolysable tannins, based on hexahydroxydiphenic acid (HHDP) esterified to a polyol core, usually glucose (Quideu et al., 2005). ETs play an important defense role like secondary metabolites in plants, where are localized in cytoplasm and cell vacuoles (Khadem and Marles, 2010). ETs are found in some flowers and fruits, mainly in leaves, stalks and peels (Ascacio-Valdés et al., 2011). Pomegranate fruit (Punica granatum L.) has been reported to be an excellent source of ETs, present in higher quantities in the peel (Robledo et al., 2008; Seeram et al., 2005), which is considered a by-product from the pomegranate juice production.
Under enzymatic or strong chemical hydrolysis, the ester bound of ETs is broken and HHDP group released (Gutiérrez-Correa et al., 2012; Huang et al., 2008a; Huang et al., 2007; Lu et al., 2008; Shi et al., 2005, Vattem and Shetty, 2002; Vattem and Shetty, 2003). Then, a molecular arrangement of HHDP forms ellagic acid (EA), an insoluble dilactone with two aromatic rings and four hydroxyl groups (Aguilera-Carbó et al., 2008; Gross, 2009).

Recent studies have reported that EA exhibits several biological activities, namely, antitumor González-Sarrias et al., 2017; Abd Elwakil et al., 2018), antimutagenic (Morosetti et al., 2017; Jaramillo-García et al., 2018), antiinflammatory (BenSaad et al., 2017), antioxidant (Ekinci Akdemir et al., 2016), antiviral (Le Donne et al., 2017; Cui et al., 2018) and antimicrobial (Sepúlveda et al., 2011; De et al., 2018).

EA, a dimeric derivative of gallic acid, has poor water solubility and it is present in the plant vacuole, either in its free forms as EA or EA derivatives, or else bound as

\footnotetext{
*Corresponding author:

Cristóbal Noé Aguilar,Food Research Department. School of Chemistry. Universidad Autónoma de Coahuila, Saltillo, 25280, Coahuila,

México. E-mail: cristobal.aguilar@uadec.edu.mx (C.N. Aguilar). Phone: +52 8444161238.
} 
water-soluble ETs (Aguilar-Zarate et al., 2018). Numerous derivatives of EA exist in plants, formed through methylation, glycosylation and metoxylation of its hydroxyl groups (Landete, 2011). Furthermore, under different reaction conditions, as microbial, chemical or enzymatic conditions, ETs change to free EA and EA derivatives changing the solubility, mobility, and reactivity of these derivatives, and as consequence, its biological capacity also changes because depends on their chemical structure. The antioxidant efficiency of ETs and EA is directly correlated with their degree of hydroxylation and decreases with the presence of a sugar moiety.

The use of enzymes for EA production has been poorly evaluated in solid-state fermentation (SSF). However, some research groups have reported the action of one or more enzymes to ellagitannins biodegradation into ellagic acid, such $\beta$-glucosidase (Shi et al., 2005; Vattem and Shetty, 2002), tannase, polyphenol oxidase (Shi et al., 2005), cellulase (Huang et al., 2008a; Huang et al., 2007), valonea tannin hydrolase (Huang et al., 2005) and ellagitannin acyl hydrolase (Aguilera-Carbó, 2009). To evaluate the effect of those enzymes activities on release of ellagic acid from ellagitannins of pomegranate, Ascacio-Valdés et al. (2014) reported that only ellagitannin acyl hydrolase or ellagitannase (EAH) was clearly associated with the ellagic acid accumulation on SSF.

The SSF is considered as the ideal fermentation process to produce fungal secondary metabolites in shorter fermentation times compared to submerged cultures; reducing costs and operation time (Hölker and Lenz, 2005; Osma et al., 2011; Velasco-Lozano et al., 2012). An important factor to be consider prior to develop a SSF process is the selection of suitable microorganisms and substrate support (Mussatto et al., 2009b). Previously, Buenrostro-Figueroa et al. (2014a) assayed four agroindustrial by-products (sugarcane, corn cobs, coconut and candelilla stalks) as matrix supports and the production of both ellagitannase enzyme and EA. Sepúlveda et al. (2012) reported the best conditions for EA production by $A$. niger GH1 in SSF using pomegranate peel as support and carbon source (moisture humidity $80 \%, 40$ h cultivation at $30^{\circ} \mathrm{C}$ ). Recently, Robledo-Olivo et al. (2018) reported the process efficiency through the estimation of the kinetic parameters of production of EA by SSF.

However, among all culture conditions previously studied and reported, the influence of inert solid supports used in SSF for EA production has not been studied, for this reason, the aim of the present work was to evaluate the production of EA by $A$. niger $\mathrm{GH} 1$ on SSF using three inert supports (perlite, polyurethane foam and nylon fiber) and partially purified ellagitannins from pomegranate peels as carbon source.

\section{MATERIALS AND METHODS}

\section{Raw material}

Pomegranate (Punica granatum L.) fruits were purchased in summer from a local market in Saltillo, Coahuila, Mexico. Fruits peels were removed, dehydrated $\left(60^{\circ} \mathrm{C}\right.$ for $\left.48 \mathrm{~h}\right)$, milled, sieving $(600 \mu \mathrm{m})$ and dried up to reach constant weight (Sepúlveda et al., 2012).

\section{Extraction and purification of ellagitannins}

Total pomegranate polyphenols (TPP) were extracted by two different methodologies. The first one was conducted according to Seeram et al. (2005) and Ascacio-Valdés et al. (2010), and we defined it as the original process (OP). The second method consisted in a modification of the OP, identified as modified process (MP). Briefly, $1 \mathrm{~kg}$ of sample was mixed with $500 \mathrm{~mL}$ of water $(1: 5 \mathrm{w} / \mathrm{v})$ and incubated at $60^{\circ} \mathrm{C}$ during $30 \mathrm{~min}$ with gently stirring. The MP for the recovery of TPP consisted on filtering the sample with muslin cloth followed by centrifugation at $3000 \mathrm{rpm}$ for 15 min, instead of filtered using Whatman 41 paper (OP). Amberlite $囚$ XAD-16 resin was packed on a glass column (4 x $61 \mathrm{~cm}$ ) to be loaded with the extract for the aqueous elution of soluble compounds. The TPP fraction was recovered with ethanol $(100 \%)$, which was thereafter recovered by evaporation. Finally, the TPP were obtained as a fine powder and the ellagic acid content was determined using the methodology described by Ascacio-Valdés et al. (2010).

\section{Supports pretreatment}

The feasibility of including perlite (PER), polyurethane foam (PUF) and nylon fibers (NF) to be used as inner support for SSF was evaluated. The PER was used as granules of $0.85 \mathrm{~mm}$ of diameter, PUF was grinded up to particle size of $1 \mathrm{~mm}$ and $\mathrm{NF}$ was cut in $1 \mathrm{~cm}$ cubes. Before use, the matrix supports were pre-treated according to Mussatto et al. (2009). Material was boiled for $10 \mathrm{~min}$, washed three times with distilled water and dried at $60^{\circ} \mathrm{C}$ until constant weight was reached. Water absorption index (WAI) was measured as reported by Anderson et al. (1970), and represents the absorption water capacity from material. The WAI value depends of the availability of the hydrophilic groups to bind water molecules, and the capacity of the support macromolecules to forms gel (Mussatto et al., 2009a). Critical humidity point (CHP) refers to the amount of water bounded to the support; for that, this water cannot be used for the metabolic functions of microorganism (Martins et al., 2011). The CHP was estimated according to Orzua et al. (2009). Packing density (PD) provides the material compaction degree, therefore, the available space for mass and energy transfer. For that, ten grams of sample were placed in a standard graduated cylinder and clamped to a shaker and vertically agitated until no change in volume during $5 \mathrm{~min}$ was observed. 


\section{Microbial strain and culture medium}

Fungal strain $A$. niger GH1 (Culture Collection DIA-UAdeC) was used due to its ability to degrade ellagitannins and release EA (Buenrostro-Figueroa et al., 2014b). Lyophilized fungal spores were suspended in sterile water and activated on potato dextrose agar (PDA-Bioxon), medium at $30^{\circ} \mathrm{C}$ for 5 days. Culture spores were collected (Tween-80 0.01\%) and counted in a Neubauaer ${ }^{\circledR}$ chamber. Pontecorvo medium was used to SSF with the following composition $\left(\mathrm{g} \mathrm{L}^{-1}\right)$ : $\mathrm{NaNO}_{3}(6.0), \mathrm{KH}_{2} \mathrm{PO}_{4}(1.52), \mathrm{KCl}(0.52), \mathrm{MgSO}_{4} .7 \mathrm{H}_{2} \mathrm{O}$ (0.52), $\mathrm{ZnSO}_{4}(0.001), \mathrm{FeCl}_{3}(0.85)$ and trace metals $\left(1 \mathrm{~mL} \mathrm{~L}^{-1}\right)$. The trace metals solution contained $\left(\mathrm{mg} \mathrm{L}^{-1}\right) \mathrm{Na}_{2} \mathrm{~B}_{4} \mathrm{O}_{7} \cdot 10 \mathrm{H}_{2} \mathrm{O}$ (10.0), $\mathrm{MnCl}_{2} \cdot 4 \mathrm{H}_{2} \mathrm{O}$ (50.0), $\mathrm{Na}_{2} \mathrm{MoO}_{4} \cdot 2 \mathrm{H}_{2} \mathrm{O}$ (50.0) and $\mathrm{CuSO}_{4} \cdot 5 \mathrm{H}_{2} \mathrm{O}(250.0)$. Total pomegranate polyphenols (TPP) were used as carbon source.

\section{Solid-state fermentation conditions}

Each support (PER, PUF and NF) was aseptically packed in column reactors previously mixed with culture medium and inoculated $\left(2 \times 10^{7}\right.$ spores per gram of support) by triplicate. Final $\mathrm{pH}$ of culture medium was adjusted at 6.5 , according to Buenrostro-Figueroa et al. (2014a). SSF was conducted at $30^{\circ} \mathrm{C}$ for $36 \mathrm{~h}$. Enzymatic extract (EE) was recover with $7 \mathrm{~mL}$ of $50 \mathrm{mM}$ citrates buffer $(\mathrm{pH}$ 5) per bioreactor, mixing, compressing and filtering $(0.45 \mu \mathrm{m})$. The EE was used to determine ellagic acid, ellagitannase activity, soluble protein and biomass. Data of ellagitannase activity was used to calculate the volumetric enzyme productivity $\left(\mathrm{g} \mathrm{L}^{-1} \mathrm{~h}^{-1}\right)$, defined as the ratio of the highest ellagitannase activity value and fermentation time $\left(\mathrm{EAH}_{P}=\mathrm{EAH} / \mathrm{t}\right)$.

\section{Analytical procedures \\ $E A$ and $E T$ s quantification}

For EA assay, TPP $(10 \mathrm{mg})$ were mixed with $1.5 \mathrm{~mL}$ of hydrolysis reagent $(190 \mu \mathrm{L}$ of concentrated sulfuric acid $(96 \%)$ and $1 \mathrm{~mL}$ of methanol). Assay tubes were hermetic closed and hydrolysis was carried out at $80^{\circ} \mathrm{C}$ for $30 \mathrm{~min}$. Assay tubes were opened under fumes hood to allow evaporation of volatile compounds and then $1.5 \mathrm{~mL}$ of distilled water was added to resuspend it. Samples were centrifuged at $3300 \mathrm{rpm}$ for $30 \mathrm{~min}$ at room temperature. The supernatant was discarded and $1.5 \mathrm{~mL}$ of ethanol $(96 \%)$ was added to obtained EA dissolution. EA was quantified by High Performance Liquid Chromatography (HPLC) (Ascacio-Valdés et al., 2010).

\section{Protein content}

Protein content was analyzed according to Bradford assay (Bradford, 1976). Fungal biomass was determined by Blix assay (Blix, 1948). For EAH activity, the protocol reported by Ascacio-Valdés et al. (2014) was used.

\section{Ellagitannase activity}

The TPP contain punicalagin and punicalin, both are molecules of ellagitannins that releases ellagic acid when are submitted to acid or enzymatic hydrolysis (AscacioValdés et al., 2014). The TPP (1 $\left.\mathrm{mg} \mathrm{mL}^{-1}\right)$ was prepared in $50 \mathrm{mM}$ citrate buffer $(\mathrm{pH}$ 5) and used like enzyme substrate. One $\mathrm{mL}$ of TPP was mixed with $50 \mu \mathrm{L}$ of EE and incubated at $60^{\circ} \mathrm{C}$ for $10 \mathrm{~min}$ in a water bath. Two controls were used: Substrate control $(1 \mathrm{~mL}$ TPP $+50 \mu \mathrm{L}$ of $50 \mathrm{mM}$ citrate buffer $\mathrm{pH}$ 5) and extract control $(1 \mathrm{~mL}$ of $50 \mathrm{mM}$ citrate buffer $\mathrm{pH} 5+50 \mu \mathrm{L}$ of enzymatic extract). Reaction was stopped by addition of absolute ethanol $(1050 \mu \mathrm{L})$. Finally, the samples were sonicated (BRANSON 2510) for $25 \mathrm{~min}$, filtered through $0.45 \mu \mathrm{m}$ membrane cartridges (Millex ${ }^{\circledR}$ ) and analyzed by HPLC for EA quantification. One unit of ellagitannase activity was defined as the amount of enzyme releasing $1 \mu \mathrm{mol}$ of EA per min at $\mathrm{pH} 5.0$ and $60^{\circ} \mathrm{C}$. The EA quantification was performed according to Ascacio-Valdés et al. (2010) on a Varian HPLC with a Diode Array Detector at $254 \mathrm{~nm}$, under the following conditions: An Optisil ODS column $(5 \mu \mathrm{m} ; 250 \mathrm{~mm} \times 4.6 \mathrm{~mm})$, temperature $30^{\circ} \mathrm{C}$ at a flow rate of $1 \mathrm{~mL} \mathrm{~min}{ }^{-1}$. Mobile phase consisted of: $\mathrm{A}=$ methanol $(100 \%), \mathrm{B}=$ acetonitrile $(100 \%)$ and $\mathrm{C}=$ acetic acid $(3 \% \mathrm{v} / \mathrm{v})$ with the following gradient: $0-10 \mathrm{~min} 100 \% \mathrm{C}$, 10-15 min 80\% C and 20\% B, 15-16 min 70\% C and 30\% $\mathrm{B}, 16-21 \mathrm{~min} 40 \% \mathrm{C}$ and $60 \% \mathrm{~B}, 21-30 \mathrm{~min} 70 \% \mathrm{C}$ and $30 \%$ B. A standard calibration curve of ellagic acid (SigmaAldrich $\left.{ }^{\circledR}\right)$ from $0-500 \mu \mathrm{g} \mathrm{L}{ }^{-1}$ was prepared.

\section{Scanning Electron Microscopy}

A Phillips XL30-ESEM (Environmental Scanning Electron Microscope) was used to visualize the spore and fungal growth. Dehydrated samples were coated with electrolytic gold $(99.99 \%$ purity) using a vacuum evaporator (Jeol Model JEE-400). Finally, samples were analyzed under vacuum with a Gaseous Secondary Electron (GSE) detector.

\section{Experimental design and data analysis}

A completely randomized design (three replicates) was used to evaluate the effect of support on ellagitannase production. Data were analyzed by ANOVA and when needed comparison of means was made using the Tukeytest using SAS 9.0 for windows, $p$-value of less than 0.05 was considered different.

\section{RESULTS AND DISCUSSION}

\section{Ellagitannins extraction}

In the present study the EA production by SSF, using partially purified ellagitannins from pomegranate peel as the only carbon source, was studied. A modified extraction process (MP) from Ascacio-Valdés et al. (2014) (OP), which involves TPP extract centrifugation, was evaluated. MP process attained an extraction yield of 7\% (70 $\mathrm{gTPP} \mathrm{kg}^{-1}$ 
of pomegranate peel), higher than the yield obtained for OP $(5.8 \%)$, even when both were reached in shorter time compared to the process proposed by Ascacio-Valdés et al. (2010). Differences on yield among the different extraction protocols might be due to the leakages of extract during the filtration stages caused for constant filter changes. Instead, when samples are centrifuged, TPP extraction time is reduced considerably ( $8 \mathrm{~h}$ less than the control treatment) and leakage is considerable reduced.

Once TPP were obtained, they were hydrolyzed with sulfuric acid (96\%) and methanol and EA was quantified by HPLC. Fig. 1 shows the peak at 28 min, corresponding to EA. The EA value obtained with MP (560 $\mathrm{mg} \mathrm{g}^{-1}$ TPP) is 1.4-fold higher than the value obtained with OP (395 $\mathrm{mg} \mathrm{g}^{-1}$ TPP). The modified extraction allows to obtain higher EA yields than those reported previously (Table 1). These results reveal that under the conditions explored in this study (centrifuged at $3000 \mathrm{rpm}$ for $15 \mathrm{~min}$ ), higher TPP yields are obtained at a shorter extraction time.

\section{Physicochemical characterization}

Materials with low water contents are required in SSF process, in order to facilitate the fungal growth and development. (Manpreet et al., 2005; Mussatto et al., 2009b). Due to the importance of water content, the support materials proposed in here were evaluated according to their WAI, CHP and PD values (Table 2). The WAI value attained in PUF $\left(9.78 \mathrm{~g} \mathrm{~g}^{-1} \mathrm{dw}\right)$ is two-fold better than those obtained with PER (3.58 $\mathrm{g} \mathrm{g}^{-1} \mathrm{dw}$ ) (Table 3). Mussatto et al. (2009a) reported a WAI value of $12.2 \mathrm{~g} \mathrm{gel} \mathrm{g}^{-1}$ dry weight for polyurethane foam. According to Robledo et al. (2008), materials with high WAI value are preferred since facilitate microorganism growth and development.

In addition, materials are required to have low $\mathrm{CHP}$ to facilitate the fungus cultivation (Martins et al., 2011, Mussatto et al., 2009a; Orzua et al., 2009). High values of $\mathrm{CHP}$ affect fungal development, due to low free-water content. All the supports tested have CHP values under $40 \%$ (Table 2), value recommended for $A$. niger strains in SSF (Moo-Young et al., 1983). Once again, the best results of CHP were found for PUF (15\%). CHP value is lower than the one reported by Mussatto et al. (2009a) for PUF $(40 \%)$. With respect to packing density (PD), we did not find any significant differences among support samples. Nevertheless, NF was difficult to manage because it tends to crosslink after ground. The high WAI and low CHP values measured for PUF, make it an excellent material to be used as a support on SSF, compared to PER and NF.

\section{EA production under SSF conditions}

For SSF process, the material used as support might provide carbon and nutrients while fermentation process

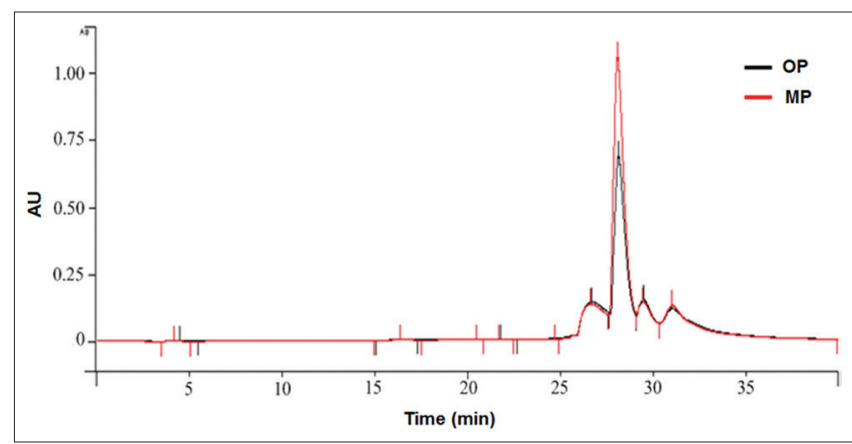

Fig 1. HPLC chromatogram from EA sample after acid hydrolysis. Gray line refers to the extraction method with the modified methodology (MP) and black line refers to original method (OP). Peaks were identified by comparison of their retention times with commercial standard of ellagic acid.

\begin{tabular}{|c|c|c|}
\hline $\begin{array}{l}\text { Yield } \\
\left.\text { (g TPP } \text { kg }^{-1} \mathrm{pp}\right)\end{array}$ & $\begin{array}{c}\text { EA } \\
\left(\mathrm{mg} \mathrm{g}^{-1} \mathrm{pp}\right)\end{array}$ & Reference \\
\hline 58 & 13 & (Seeram et al. 2005) \\
\hline 53 & 34 & (Aguilera-Carbó, 2009) \\
\hline 60 & 28 & $\begin{array}{l}\text { (Ascacio-Valdes et al., } \\
\text { 2010) }\end{array}$ \\
\hline 58 & 26 & Present study (OP) \\
\hline 70 & 37 & Present study (MP) \\
\hline
\end{tabular}

Table 2: Water absorption index (WAI), critical humidity point (CHP) and packing density (PD) for the different synthetic materials used as supports

\begin{tabular}{lccc}
\hline Support & WAI $\left(\mathbf{g ~ g}^{-1} \mathbf{d w}\right)$ & CHP $(\%)$ & PD $\left(\mathbf{g ~ c m}^{-3}\right)$ \\
\hline Perlite (PER) & 3.58 & 25.5 & 0.07 \\
Polyurethane foam (PUF) & 9.78 & 15 & 0.07 \\
Nylon fibers (NF) & 7.65 & 21 & 0.08 \\
\hline
\end{tabular}

Table 3: Parameters estimated during ellagic acid production by $A$. niger $\mathrm{GH} 1$

\begin{tabular}{lcc} 
Support & Max EAH $\left(\mathbf{U ~ L}^{-1}\right)$ & EAHp $\left(\mathbf{U ~ L}^{-1} \mathbf{h}^{-1}\right)$ \\
\hline PER & 2630.81 & 109.62 \\
PUF & 3213.57 & 133.90 \\
FN & 2436.57 & 101.52 \\
\hline
\end{tabular}

is occurring, or as used in this study, as bonding surface for fungal invasion. Figure 2 shows the kinetics of biomass production of $A$. niger $\mathrm{GH} 1$ in SSF, reaching a rapid mycelial invasion on support trabecules. The mycelia growth of the fungi allowed the surface support invasion and penetration into the substrate matrix to reach the nutrients embedded (Barrios-González, 2012; Graminha et al., 2008). A. niger GH1 presents a fast biomass production reaching the maximum value (110 $\mathrm{mg} \mathrm{g}^{-1}$ support) at $24 \mathrm{~h}$ cultivation for all the support materials tested (Fig. 2).

Environmental scanning electron microscopy of samples is showed in Fig. 3, where it was possible to observe 
the fungal spores all over the supports. PER has a great number of porous particles (Fig. 3.A), the same as PUF

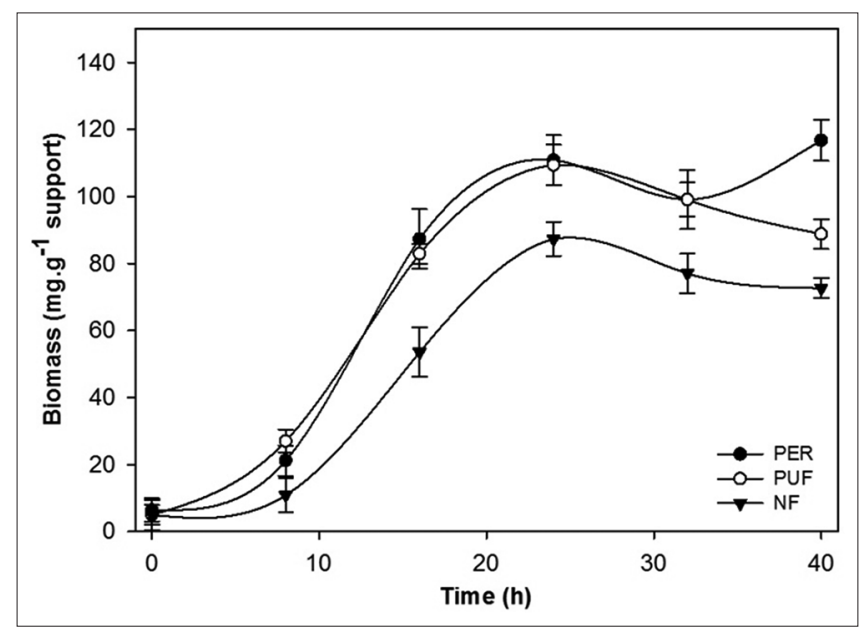

Fig 2. Kinetics of biomass production by $A$. niger $\mathrm{GH} 1$ in SSF using $\operatorname{PER}(\bullet)$, PUF $(\circ)$ and NF $(\boldsymbol{\nabla})$ as supports.
(Fig. 3.B and 3.C). These cavities are used for fungal invasion. Fungal spores are attached to surface trough different mechanisms including complex interactions of physical and biological process such as hydrophobicity, electrostatic charges and surface roughness (GutiérrezCorrea et al., 2012; Linder et al., 2005). Figures 3.D and 3.E show the fungal invasion on and inside cavities of PER and PUF, respectively, at 40 h of culture. A. niger GH1 spores with a rough structure surface were observed on all the supports (Fig. 3.E). Adhesion is due to small secreted proteins exclusive of filamentous fungi, called hydrophobins (Linder et al., 2005; Villena and Gutiérrez-Correa, 2006).

Fig. 4 shows the EA accumulation, which was analyzed by HPLC. An increment of this phenolic compound was found due to the enzymatic hydrolysis of TPP. A. niger GH1 could grow and release EA, which its maximum concentration was achieved at $24 \mathrm{~h}$ in all supports tested. After that time, the concentration diminished.
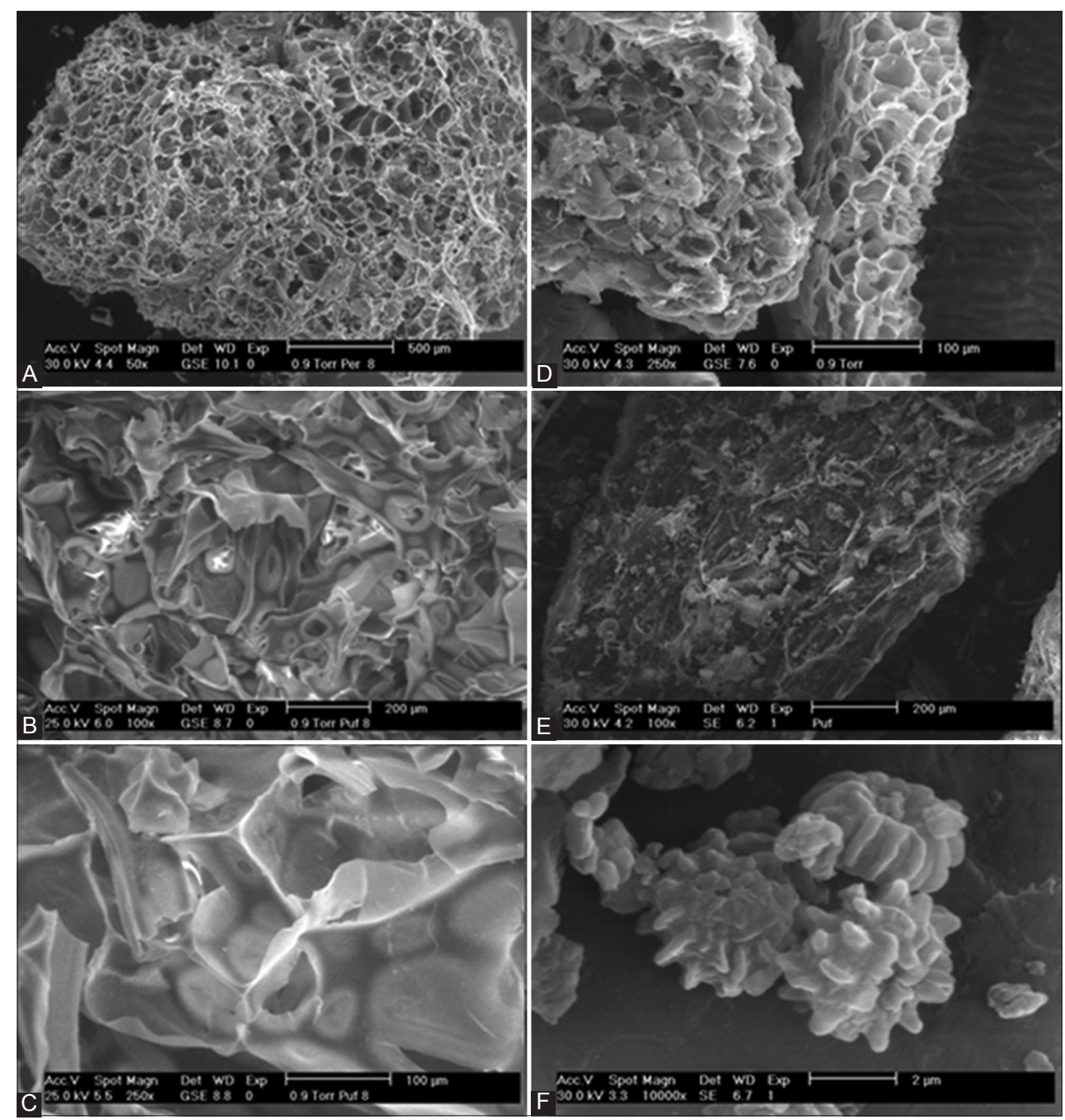

Fig 3. ESEM micrographs of A) PER support (50x) without fungus, pore size estimation $50 \mu \mathrm{m}$. B) and C) PUF support (100 $x$ and $250 \mathrm{x}$, respectively) without fungus, pore size estimation $100 \mu \mathrm{m}$. D) Mycelial fungal invasion on PER (250 x). E) Fungal growth in PUF (250x) and F) Spores from A. niger GH1 (10000 x) with a pore size estimation of $4.35 \mu \mathrm{m}$. 


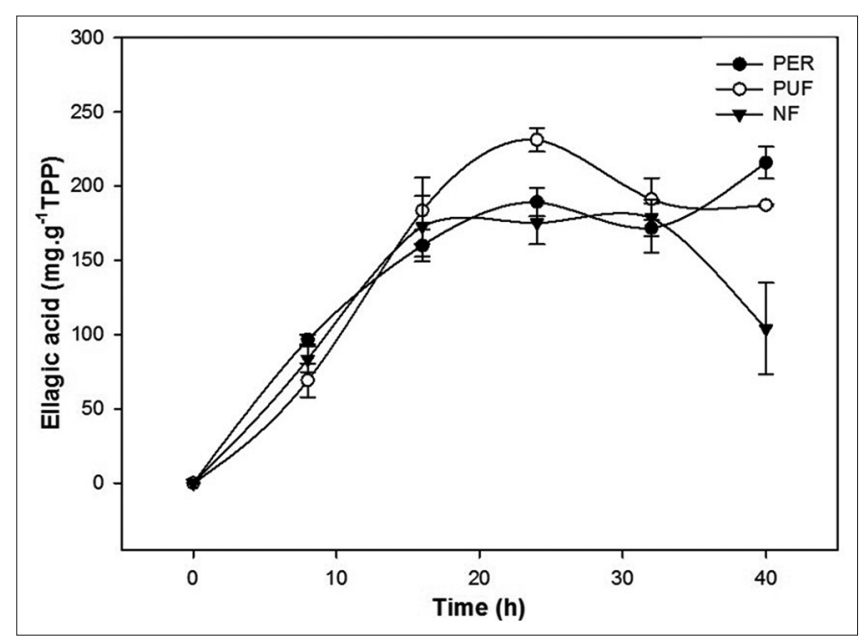

Fig 4. EA production by $A$. niger GH1 on PER (•), PUF (०) and NF $(\boldsymbol{\nabla})$ under SSF conditions.

The highest EA production was observed on PUF at $24 \mathrm{~h}$ of culture (231.22 $\left.\mathrm{mg} \mathrm{g}^{-1} \mathrm{TPP}\right)$. The high WAI and low CHP values for PUF, could promote a best solubility and transport of nutrients, and therefore, improves the availability of nutrients for the fungal. No significant differences in EA production between PER (189.29 $\left.\mathrm{mg} \mathrm{g}^{-1} \mathrm{TPP}\right)$ and NF (175.31 $\left.\mathrm{mg} \mathrm{g}^{-1} \mathrm{TPP}\right)$ were observed at $24 \mathrm{~h}$ of culture $(\mathrm{p} \leq 0.05)$.

In a SSF by $A$. niger GH1 using pomegranate peel powder as substrate, Sepúlveda et al. (2012) reported the maximum EA accumulation of $132 \mathrm{mg} \mathrm{g}^{-1}$ pomegranate peel using optimized culture conditions. Nevertheless, authors obtained the extracts with a mixture of ethanol and $0.01 \%$ formic acid (v/v), which promotes a better affinity of EA, but can denature the enzyme. In the present study, extracts were obtained by adding $50 \mathrm{mM}$ citrate buffer $\mathrm{pH}$ 5.0. In optimized conditions using different strains of $A$. niger, De la Cruz-Quiroz (2014) reported $148 \mathrm{mg} \mathrm{g}^{-1}$ and $114 \mathrm{mg} \mathrm{g}^{-1}$ of EA production from pomegranate ellagitannins, using A. niger $\mathrm{PSH}$ y $A$. niger $\mathrm{GH} 1$, respectively. In the present study, the EA obtained using PUF (231.22 $\mathrm{mg} \mathrm{g}^{-1} \mathrm{TPP}$ ) was 5.49 and 2.02-fold higher than those values reported by Ascacio-Valdés et al. (2014) and De la Cruz-Quiroz (2014) using the same strain and TPP as carbon and inductor source.

Volumetric enzyme productivity (EAHp) was determined and result are shown on the Table 3. EAHp values obtained in this study are notable promising compared to those previously reported for $A$. niger SHL 6 using valonea tannins as a carbon source in liquid culture, reaching values of $0.92 \mathrm{U} \mathrm{L}^{-1} \mathrm{~h}^{-1}$ (Huang et al., 2007). Also, Aguilera-Carbó et al. (2009) reported the production of ellagic acid from creosote bush by $A$. niger $\mathrm{GH} 1$ obtaining an $\mathrm{EAH}_{p}$ of $1.22 \mathrm{U}$ $\mathrm{L}^{-1} \mathrm{~h}^{-1}$. In a different work in which was used $A$. niger $\mathrm{GH} 1$,
PUF as support and pomegranate extracts as carbon source produced an EAH $p$ of $0.92 \mathrm{U} \mathrm{L}^{-1} \mathrm{~h}^{-1}$ (Aguilera-Carbó, 2009).

Recently, it was shown the inductive effect of a purified extract of pomegranate ellagitannins in the production of ellagitannase by $A$. niger under SSF, authors reported an increase in the $\mathrm{EAH}_{\phi}$ (Ascacio-Valdés et al., 2014). The effect of differents sources of polyphenols (cranberry, creosote bush and pomegranate) and fungal strains (A. niger $\mathrm{GH} 1$, $A$. niger $\mathrm{HT} 4$ and $A$. niger $\mathrm{PSH}$ ) on $\mathrm{EA}$ release have been evaluated (Sepúlveda et al., 2016). The best combination was $A$. niger $\mathrm{HT} 4$ on pomegranate peels polyphenols (PP), reaching $350.21 \mathrm{mg} \mathrm{g}^{-1}$. However, use of $A$. niger $\mathrm{GH} 1$ on PP showed maximum ellagic acid of $163.03 \mathrm{mg} \mathrm{g}^{-1}$. In this study, the values of EA obtained using pomegranate ellagitannins as inducers (231.22 $\left.\mathrm{mg} \mathrm{g}^{-1} \mathrm{TPP}\right)$ are higher than the obtained by Sepúlveda et al. (2012) using pomegranate peel powder as inducers under optimized culture conditions $\left(132 \mathrm{mg} \mathrm{g}^{-1}\right)$. The partially purified ellagitannins could be considered as a complex substrate and $A$. niger $\mathrm{GH} 1$ had to secrete higher amounts of the enzyme in order to break the ester linkages among HHDP group and glycosides. This suggests the induction of ellagitannase enzyme by partially purified ellagitannins. Ascacio-Valdés et al. (2014) reported the presence of a specific enzyme for the ellagitannins degradation, and the presence of this enzyme was attributed to a similar biochemical mechanism of regulation of the fungal metabolism.

In the selection of the support material for SSF process, it is of great importance the evaluation of costs and the availability of material, as well as the environmental impact of the solids produced. The use of PUF as a matrix for the culture media absorption and attachment matrix for the fungal growth provides important advantages, such as higher production titers and productivity. PUF can be used as an excellent inert support in SSF for the production of bioactive compounds; moreover, its use may significantly decrease costs production, due to increase the enzymatic productivity compared to the other materials evaluated, facilitating the recovery of valueadded compounds, and the reutilization of the support or its use for conducting semi-continuous processes. The development of bioprocess for ellagitannase production and its application in ellagitannins biodegradation for ellagic acid production confers enormous economic and environmental advantages over chemical methods.

\section{CONCLUSIONS}

In the present study, high yield of EA was obtained from the SSF using partially purified ellagitannins from pomegranate peel as only carbon source. A modified TPP extraction 
process provided higher yields (70 $\mathrm{g}$ TPP kg-1 $\mathrm{pp}$ ) and ellagic acid (560 $\mathrm{mg} \mathrm{g}^{-1} \mathrm{TPP}$ ) values in a shorter time compared to the original process. The high WAI and low CHP values found for PUF make it an excellent material to be used as a support on SSF, compared to PER and NF. A. niger GH1 was able to grow in all the supports tested, however the use of PUF provides higher ellagitannase activity $\left(3213 \mathrm{U} \mathrm{L}^{-1}\right)$ and ellagic acid (231.22 $\left.\mathrm{mg} \mathrm{g}^{-1} \mathrm{TPP}\right)$ production at $24 \mathrm{~h}$. Developed bioprocess proposes an alternative to produce EA a low cost, diminished the environmental damage occasioned by the use of chemical agents. Also, fermented support can be reused or implied in semi-continuous process to EA production.

\section{ACKNOWLEDGEMENTS}

Authors thanks to National Council for Science and Technology (CONACYT, Mexico) for the financial support and postgraduate scholarships (269054) given.

\section{AUTHOR'S CONTRIBUTION}

All authors contributed extensively to the work presented in this article. J.B.F. and C.N.A.: Designed and performed research, wrote and revised the manuscript. L.S.: Contributed to the development of experimental part and reviewed the manuscript. J.A.A.V.: Supported in HPLC analysis and reviewed the manuscript. A.P.B.: Helped in design research and discussion. M.A.A.G.: Performed the ESEM analysis. All authors read and approved the final manuscript.

\section{REFERENCES}

Abd Elwakil, M. M., M. T. Mabrouk, M. W. Helmy, E. Z. A. Abdelfattah, S. K. Khiste, K. A. Elkhodairy and A. O. Elzoghby. 2018. Inhalable lactoferrin-chondroitin nanocomposites for combined delivery of doxorubicin and ellagic acid to lung carcinoma. Nanomedicine. 13(16): 2015-2035.

Aguilera-Carbó, A., C. Augur, L. A. Prado-Barragan, E. FavelaTorres and C. N. Aguilar. 2008. Microbial production of ellagic acid and biodegradation of ellagitannins. Appl. Microbiol. Biotechnol. 78: 189-199.

Aguilera-Carbó, A., J. Hernández, C. Augur, L. A. Prado-Barragan, E. Favela-Torres and C.N. Aguilar. 2009. Ellagic acid production from biodegradation of Creosote bush ellagitannins by Aspergillus niger in solid state culture. Food Bioprocess. Technol. 2: 208-212.

Aguilera-Carbó, F. A. 2009. Ellagic Acid Production: Enzymatic Studies. (Doctoral dissertation), Universidad Autónoma Metropolitana-Iztapalapa. México.

Anderson, R. A., H. F. Conwa and A. J. Peplinski. 1970. Gelatinization of corn grits by roll cooking, extrusion cooking and steaming. Starch-Stärke. 22: 130-135.

Ascacio-Valdés, J. A., A. Aguilera-Carbó, J. Martínez-Hernández, R. Rodríguez-Herrera and Aguilar, C.N. 2010. Euphorbia antisyphilitica residues as a new source of ellagic acid. Chem. Pap. 64: 528-532.
Ascacio-Valdés, J. A., J. J. Buenrostro-Figueroa, A. Aguilera-Carbó, A. Prado-Barragán, R. Rodríguez-Herrera and C. Aguilar. 2011. Ellagitannins: Biosynthesis, biodegradation and biological properties. J. Med. Plants Res. 5: 4696-4703.

Ascacio-Valdés, J. A., J. Buenrostro, R. De la Cruz, L. Sepúlveda, A. Aguilera, A. Prado, J. C. Contreras, R. Rodríguezand C. N. Aguilar. 2014. Fungal biodegradation of pomegranate ellagitannins. J. Basic Microbiol. 54: 28-34.

Barrios-González, J. 2012. Solid-state fermentation: Physiology of solid medium, its molecular basis and applications. Process Biochem. 47: 175-185.

BenSaad, L. A., K. H. Kim, C. C. Quah, W. R. Kim and M. Shahimi. 2017. Anti-inflammatory potential of ellagic acid, gallic acid and punicalagin $A$ and $B$ isolated from Punica granatum. BMC Complement Altern. Med. 17(1): 47.

Blix, G. 1948. The determination of hexosamines according to elson and morgan. Acta Chem. Scand. 2: 467-473.

Bradford, M. M. 1976. A rapid and sensitive method for the quantitation of microgram quantities of protein utilizing the principle of protein-dye binding. Anal. Biochem. 72: 248-254.

Buenrostro-Figueroa, J., J. A. Ascacio-Valdés, L. Sepúlveda, R. De la Cruz, A. Prado-Barragán, M. A. Aguilar-González, R. Rodríguez and C. N. Aguilar. 2014a. Potential use of different agroindustrial by-products as supports for fungal ellagitannase production under solid-state fermentation. Food Bioprod. Process. 92: 376-382.

Buenrostro-Figueroa, J., S. Huerta-Ochoa, A. Prado-Barragán, J. A. Ascacio-Valdés, L. Sepúlveda, R. Rodríguez, A. AguileraCarbó and C. N. Aguilar. 2014b. Continuous production of ellagic acid in a packed-bed reactor. Process Biochem. 49: 1595-1600.

Cui, Q., R. Du, M. Anantpadma, A. Schafer, L. Hou, J. Tian, R. A. Davey, H. Cheng and L. Rong. 2018. Identification of ellagic acid from plant Rhodiola rosea L. as an anti-Ebola virus entry inhibitor. Viruses. 10(4): 152.

De, R., A. Sarkar, P. Ghosh, M. Ganguly, B. C. Karmakar, D. R. Saha, A. Halder, A. Chowdhury and A. K. Mukhopadhyay. 2018. Antimicrobial activity of ellagic acid against Helicobacter pylori isolates from India and during infections in mice. J. Antimicrob. Chemother. 73(6): 1595-1603.

De la Cruz, R., J. Ascacio, J. Buenrostro, L. Sepúlveda, R. Rodríguez, A. Prado-Barragán, J. C. Contreras, A. Aguilera and C. N. Aguilar. 2014. Optimization of ellagitannase production by Aspergillus niger $\mathrm{GH} 1$ by solid-state fermentation. Prep. Biochem. Biotechnol. 45: 617-631.

Ekinci Akdemir, F. N., İ. Gülçin, B. Karagöz, R. Soslu and S. H. Alwasel. 2016. A comparative study on the antioxidant effects of hesperidin and ellagic acid against skeletal muscle ischemia/ reperfusion injury. J. Enzyme Inhib. Med. Chem. 31(4): 114-118.

González-Sarrias, A., M. Á. Núñez-Sánchez, R. García-Villalba, F. A. Tomás-Barberán and J. C. Espín. 2017. Antiproliferative activity of the ellagic acid-derived gut microbiota isourolithin $A$ and comparison with its urolithin $A$ isomer: The role of cell metabolism. Eur. J. Nutr. 56(2): 831-841.

Graminha, E. B. N., A. Z. L. Gonçalves, R. D. Pirota, M. A. Balsalobre, R. Da Silva and E. Gomes, 2008. Enzyme production by solidstate fermentation: Application to animal nutrition. Anim. Feed Sci. Technol. 144: 1-22.

Gross, G. G. 2009. Biosynthesis of ellagitannins: Old ideas and new solutions. In S. Quideau (Ed.), Chemistry and Biology of Ellagitannins: An Underestimated Class of Bioactive Plant Polyphenols. World Scientific Publishing. Singapore, pp. 94-118.

Gutiérrez-Correa, M., Y. Ludeña, G. Ramage and G. Villena. 2012. Recent advances on filamentous fungal biofilms for industrial uses. Appl. Biochem. Biotechnol. 167: 1235-1253. 
Hölker, U and J. Lenz. 2005. Solid-state fermentation - Are there any biotechnological advantages? Curr. Opin. Microbiol. 8: 301-306.

Huang, W., J. Ni and A. J. Borthwick. 2005. Biosynthesis of valonia tannin hydrolase and hydrolysis of valonia tannin to ellagic acid by Aspergillus SHL 6. Process Biochem. 40: 1245-1249.

Huang, W., H. Niu, Z. Li, W. Lin, G. Gong and W. Wang. 2007. Effect of ellagitannin acyl hydrolase, xylanase and cellulase on ellagic acid production from cups extract of valonia acorns. Process Biochem. 42: 1291-1295.

Huang, W., Z. Li, H. Niu, L. Li, W. Lin and J. Yang. 2008a. Utilization of acorn fringe for ellagic acid production by Aspergillus oryzae and Endomyces fibuliger. Bioresour. Technol. 99: 3552-3558.

Huang, W., H. Niu, Z. Li, L. Li and W. Wang. 2008b. Ellagic acid from acorn fringe by enzymatic hydrolysis and combined effects of operational variables and enzymes on yield of the production. Bioresour. Technol. 99: 1518-1525.

Jaramillo-García, V., C. Trindade, E. Lima, T. N. Guecheva, I. Villela, W. Martinez-Lopez, D. S. Correa, A. B. F. Ferraz, S. Moura, M. Q. Sosa, J. Da Silva and J. A. P. Henriques. 2018. Chemical characterization and cytotoxic, genotoxic, and mutagenic properties of Baccharis trinervis (Lam, Persoon) from Colombia and Brazil. J. Ethnopharmacol. 213: 210-220.

Khadem, S and R. Marles. 2010. Monocyclic phenolic acids; Hydroxy- and polyhydroxybenzoic acids: Occurrence and recent bioactivity studies. Molecules. 15: 7985-8005.

Khanbabaee, K and T. van Ree. 2001. Tannins: Classification and definition. Nat. Prod. Rep. 18: 641-649.

Landete, J. M. 2011. Ellagitannins, ellagic acid and their derived metabolites: A review about source, metabolism, functions and health. Food Res. Int. 44(5): 1150-1160.

Le Donne, M., M. Lentini, A. Alibrandi, V. Salimbeni, F. Mazzeo, O. Triolo and R. D'Anna. 2017. Antiviral activity of ellagic acid and Annona muricata in cervical HPV related pre-neoplastic lesions: A randomized trial. J. Funct. Foods. 35: 549-554.

Linder, M. B. 2009. Hydrophobins: Proteins that self assemble at interfaces. Curr. Opin. Colloid Interface Sci. 14: 356-363.

Linder, M. B., G. R. Szilvay, T. Nakari-Setälä and M. E. Penttilä. 2005. Hydrophobins: The Protein-amphiphiles of filamentous fungi. FEMS Microbiol. Rev. 29: 877-896.

Lu, J., K. Ding and Q. Yuan. (2008). Determination of punicalagin isomers in pomegranate husk. Chromatographia. 68: 303-306.

Manpreet, S., S. Sawraj, D. Sachin, S. Pankag and U. C. Banerjee. 2005. Influence of process parameters on the production of metabolites in solid-state fermentation. Malays. J. Microbiol. 1: 1-9.

Martins, S., S. I. Mussatto, G. Martínez-Avila, J. MontañezSaenz, C. N. Aguilar and J. A. Teixeira. 2011. Bioactive phenolic compounds: Production and extraction by solid-state fermentation. A review. Biotechnol. Adv. 29: 365-373.

Moo-Young, M., A. Moreira and R. Tengerdy. 1983. Principles of solid substrate fermentation. In Smith, J., D. Berry and B. Kristiansen (Ed.), The Filamentous Fungi. Edward Arnold Publishers, London, pp117-144.

Morosetti, G., A. A. Criscuolo, F. Santi, C. F. Perno, E. Piccione and M. Ciotti. 2017. Ellagic acid and Annona muricata in the chemoprevention of HPV-related pre-neoplastic lesions of the cervix. Oncol. Lett. 13(3): 1880-1884.

Mussatto, S. I., C. N. Aguilar, L. R. Rodrigues and J. A. Teixeira. 2009a. Colonization of Aspergillus japonicus on synthetic materials and application to the production of fructooligosaccharides.
Carbohydr. Res. 344: 795-800.

Mussatto, S. I., C. N. Aguilar, L. R. Rodrigues and J. A. Teixeira. 2009b. Fructooligosaccharides and $\beta$-fructofuranosidase production by Aspergillus japonicus immobilized on lignocellulosic materials. J. Mol. Catal. B: Enzym. 59: 76-81.

Orzua, M. C., S. I. Mussatto, J. C. Contreras-Esquivel, R. Rodriguez, H. de la Garza, J. A. Teixeira and C. N. Aguilar. 2009. Exploitation of agroindustrial wastes as immobilization carrier for solid-state fermentation. Ind. Crops Prod. 30: 24-27.

Osma, J. F., J. L. Toca-Herrera and S. Rodríguez-Couto. 2011. Cost analysis in laccase production. J. Environ. Manage. 92: 2907-2912.

Quideu, S., M. Jourdes, D. Lefeuvre, D. Montaudon, C. Saucier, Y. Glories, P. Pardon and P. Pourquier. 2005. The chemistry of wine polyphenolic C-glycosidic ellagitannins targeting human topoisomerase II. Chem. Eur. J. 11: 6503-6513.

Robledo, A., A. Aguilera-Carbó, R. Rodriguez, J. L. Martinez, Y. Garza and C. N. Aguilar. 2008. Ellagic acid production by Aspergillus niger in solid state fermentation of pomegranate residues. J. Ind. Microbiol. Biotechnol. 35: 507-513.

Robledo, A., A. F. Aguilera-Carbo, A. Prado-Barragan, L. SepulvedaTorre, R. Rodríguez-Herrera, J. C. Contreras-Esquivel and C. N. Aguilar. 2018. Kinetics of ellagic acid accumulation by solidstate fermentation. In: Theoretical Models and Experimental Approaches in Physical Chemistry. Apple Academic Press, pp293-306.

Seeram, N., R. Lee, M. Hardy and D. Heber. 2005. Rapid large scale purification of ellagitannins from pomegranate husk, a by-product of the commercial juice industry. Sep. Purif. Technol. 41: 49-55.

Sepúlveda, L., J. A. Ascacio-Valdés, R. Rodriguez-Herrera, A. Aguilera-Carbó and C. N. Aguilar. 2011. Ellagic acid: Biological properties and biotechnological development for production processes. Afr. J. Biotechnol. 10: 4518-4523.

Sepúlveda, L., A. Aguilera-Carbó, J. A. Ascacio-Valdés, R. RodríguezHerrera, J. L. Martínez-Hernández and C. N. Aguilar. 2012. Optimization of ellagic acid accumulation by Aspergillus niger $\mathrm{GH} 1$ in solid state culture using pomegranate shell powder as a support. Process Biochem. 47: 2199-2203.

Sepúlveda, L., R. de la Cruz, J. J. Buenrostro, J. A. Ascacio-Valdés, A. Aguilera-Carbó, A. Prado, R. Rodríguez-Herrera and C. N. Aguilar. 2016. Effect of different polyphenol sources on the efficiency of ellagic acid release by Aspergillus niger. Rev. Argent. Microbiol. 48: 71-77.

Shi, B., Q. He, K. Yao, W. Huang and Q. Li. 2005. Production of ellagic acid from degradation of valonea tannins by Aspergillus niger and Candida utilis. J. Chem. Technol. Biotechnol. 80: 1154-1159.

Vattem, D. A and K. Shetty. 2002. Solid-state production of phenolic antioxidants from cranberry pomace by Rhizopus oligosporum. Food Biotechnol. 16: 189-210.

Vattem, D. A and K. Shetty. 2003. Ellagic acid production and phenolic antioxidant activity in cranberry pomace (Vaccinium macrocarpon) mediated by Lentinus edodes using a solid-state system. Process Biochem. 39: 367-379.

Velasco-Lozano, S., T. Volke-Sepulveda and E. Favela-Torres. 2012. Lipases production by solid-state fermentation: The case of Rhizopus homothallicus in perlite. In: G. Sandoval (Ed.), Lipases and Phospholipases. Methods in Molecular biology (Methods and Protocols). Humana Press, New York, pp. 227-237.

Villena, G. K and M. Gutiérrez-Correa. 2006. Production of cellulase by Aspergillus niger biofilms developed on polyester cloth. Lett. Appl. Microbiol. 43: 262-268. 